\title{
СТВОРЕННЯ КНИГИ СПОГАДІВ УЧАСНИКІВ АТО: ВІД ЗАДУМУ ДО ГОТОВОГО ВИДАННЯ
}

\section{К. Л. Сізова, Н. М. Алексеснко}

Кременчуцький національний університет імені Михайла Остроградського

вул. Першотравнева, 20, 39600, м. Кременчук, Україна. E-mail: sizovakl@ ramblerl.ru

Висвітлено процес створення книги спогадів учасників АТО і волонтерів Кременчука, у якому взяли участь студенти і викладачі кафедри філології та видавничої справи Кременчуцького національного університету імені Михайла Остроградського. Розглянуто різні етапи підготовки видання - від розробки концепції до тиражування. Особлива увага приділяється методу, покладеному в основу видання, а саме методу наративних інтерв'ю. Підкреслюється міждисциплінарний характер напряму усної історії. Вивчається вплив спільної роботи над проектом викладачів і студентів на формування фахових компетентностей у майбутніх журналістів, редакторів $\mathrm{i}$ видавців. Доводиться, що залучення студентської молоді до створення суспільно-значущого видання має дидактичне та виховне значення.

Ключові слова: книга спогадів, учасники АТО, метод наративних інтерв’ю, усна історія, фахові журналістські компетентності.

\section{СОЗДАНИЕ КНИГИ ВОСПОМИНАНИЙ УЧАСТНИКОВ АТО: ОТ ЗАМЫСЛА К ГОТОВОМУ ИЗДАНИЮ}

\section{К. Л. Сизова, Н. М. Алексеенко}

Кременчугский национальный университет имени Михаила Остроградского

ул. Первомайская, 20, 39600, г. Кременчуг, Украина. E-mail: sizovak1@ ramblerl.ru

Освещается процесс создания книги воспоминаний участников АТО и волонтеров Кременчуга, в котором приняли участие студенты и преподаватели кафедры филологии и издательского дела Кременчугского национального университета имени Михаила Остроградского. Рассматриваются различные этапы подготовки издания - от разработки концепции до тиражирования. Особое внимание уделяется методу, положенному в основу издания, а именно методу нарративных интервью. Подчеркивается междисциплинарный характер направления устной истории. Изучается влияние совместной работы над проектом преподавателей и студентов на формирование профессиональных компетенций у будущих журналистов, редакторов и издателей. Доказывается, что привлечение студенческой молодежи к созданию общественно-значимого издания имеет дидактическое и воспитательное значение.

Ключевые слова: книга воспоминаний, участники АТО, метод нарративных интервью, устная история, профессиональные журналистские компетентности.

АКТУАЛЬНІСТЬ РОБОТИ. Залучення студентів i викладачів до спільної роботи над науководослідницьким проектом є ефективним шляхом формування фахових компетентностей у майбутніх спеціалістів. Таким спільним проектом стало створення книги спогадів учасників АТО і волонтерів Кременчука, у якому взяли участь студенти і викладачі кафедри філології та видавничої справи Кременчуцького національного університету імені Михайла Остроградського.

У сучасній гуманітаристиці напрям усної історії є досить популярним. Для сьогоденної України, яка переживає складний етап становлення національної держави, збір свідчень різних верств населення про події останніх років є дуже важливим. Процеси, які відбуваються на Україні, їх вплив на людей потребують уваги і наукового осмислення з точки зору різних галузей гуманітарного знання, зокрема - наук про соціальні комунікації.

Актуальною науковою проблемою є підготовка різнотипних видань наративних інтерв'ю - не лише наукових, але й публіцистичних, призначених для широкої читацької аудиторії.

Залучення студентів, які опановують журналістський фах, до підготовки збірок спогадів $є$ підгрунтям формування професійних компетентностей, а саме: розробки концепції видання, інтерв'ювання, редакторського опрацювання зібраних матеріалів, підбору і обробки фотоілюстрацій тощо.
Мета статті полягає у висвітленні процесу створення науковим колективом кафедри філології та видавничої справи Кременчуцького національного університету імені Михайла Остроградського книги спогадів добровольців АТО і волонтерів Кременчука.

Дослідження було проведено із застосуванням системного й міждисциплінарного підходів, за допомогою загальнонаукових методів: аналізу, синтезу, порівняння, індукції й дедукції, а також описового методу.

МАТЕРІАЛ І РЕЗУЛЬТАТИ ДОСЛІДЖЕНЬ. Напрям усної історії, який виник у другій половині минулого століття у західній історичній науці, грунтовно розглядається у працях як зарубіжних (М. Г. Кенни [1], Г. Розенталь [2]), так і вітчизняних вчених (Г. Грінченко [3], О. Кісь [4], Т. Нагайко [5]).

Дослідники акцентують увагу на тому, що напрям інтегрує різні гуманітарні науки. Зокрема, голова Української асоціації усної історії Г. Грінченко зауважує, що міждисциплінарний характер усної історії протягом усього періоду існування напряму стимулював активний діалог іiі представників із фахівцями інших спеціальностей, надавши можливості обгрунтованого запозичення методик запису й аналізу автобіографічних оповідей, розроблених у рамках суміжних галузей соціально-гуманітарного знання [3].

Т. Нагайко визначає усну історію як спільний 
метод у науковому відтворенні соціокультурної реальності. До спектру суміжних галузей, що найближче знаходяться до усної історії, учений зараховує також і журналістику, яка хоча сама й залишається осторонь процесу історичної реконструкції минулого у науковому плані, проте продукт цієї галузі (статті періодичних газетних та журнальних видань), створений на основі методу інтерв'ювання, давно став невід'ємною складовою джерельної бази історичних досліджень [5]. Г. Дьяковська досліджує зміст наративу як складової частини дискурсивної реальності, що формує специфічні форми сприйняття соціального досвіду, розкриває сутність наративу як багатовимірного феномену та здійснює опис зазначеного феномену як форми знання, яке допомагає людині сприймати соціальну дійсність і саму себе, вказує, що зазначений феномен з усіма його особливостями є способом переживання часу, трансформує й конституюе реальність [6]. Аналіз зв'язків усної оповіді з реальною подією, яка описується, показує, що, незважаючи на можливі неточності, усна оповідь розширює реальність.

О. Ярощук вважає усну історію методом запису свідчень та результатом запису - розповідь свідка, очевидця, людини, яка має спогади про минуле. Порівняно з класичним журналістським інтерв'ю усна історія цікавиться персональними поглядами, згадками й емоціями. Зміст таких інтерв'ю - спогади про минуле, а не коментарі про сучасність. Подруге, інтерв'ю зі свідками тривають довго - інколи дві, три, чотири години, аби оповідач розповів якомога більше фактів зі свого життя [7].

Біографія є унікальним джерелом - вона, на думку О. Кісь, дає змогу зосередитись на індивідуальному житті, що вписане у безпосереднє соціокультурне середовище, отож роздуми особи про іï власне життя та соціальне, політичне чи культурне середовище одночасно перебувають у полі уваги дослідника [4]. Біографія виступає своєрідною енциклопедією доби, адже містить не лише інформацію про подіï, але й про систему цінностей наратора. Саме вона, як зауважує Г. Розенталь, «визначає врештірешт те, яким чином біограф відтворює своє минуле й приймає рішення стосовно того, який пережитий ним досвід вважати суттєвим та включати у свою оповідь» [8]. Т. Лапан здійснює спробу аналізу «автобіографічної пам'яті» жінок, які перебували у зоні збройного конфлікту [9].

Поштовхом до створення книги «Герої згадують...» стало звернення ветеранів АТО Кременчука до колективу кафедри філології та видавничої справи Кременчуцького національного університету імені Михайла Остроградського з проханням зібрати і видати спогади безпосередніх учасників трагічних для України подій - війни на сході країни.

Головною метою авторів книги стало висвітлення української історії останніх чотирьох років на прикладі окремого міста. Автори поставили перед собою завдання зібрати усні історії бійців і волонтерів Кременчука, безпосередніх учасників подій на сході України, щоб простежити епізод за епізодом у хронологічній послідовності, починаючи від подій на Майдані, що відбувалося насправді, показати, що довелося пережити людям у місцях бойових дій, в полоні, і що вони змогли зробити задля збереження країни. В якості основного було обрано метод наративних інтерв'ю. Т. Пастушенко, аналізуючи сучасні підходи до проведення інтерв'ю та їх види, зазначає, що наративне інтерв'ю - вільне інтерв'ю, яке має вигляд розповіді про своє життя без втручання інтерв'юера, котрий задає лише загальну спрямованість оповіді, що очікується. Передбачається, що під час вільного викладу в пам'яті оповідача асоціативно випливають у першу чергу ті епізоди і моменти, котрі мають найбільшу суб'єктивну цінність [10].

На першому етапі було проведено інтерв'ювання понад сімдесяти осіб. Відбір опитуваних проводився за поданням місцевих громадських об'єднань та Департаменту соціального захисту населення та питань АТО виконавчого комітету Кременчуцької міської ради. До переліку потрапили представники різних соціальних груп - кадрові військові, мобілізовані до лав ЗСУ, бійці добровольчих батальйонів, керівники підприємств, бізнесмени, громадські діячі, пересічні громадяни. Спільним для усіх них було те, що вони на власні очі бачили, що відбувалося у зоні АТО і особисто брали участь у подіях.

Слід зазначити, що кафедрі був наданий список зі ста двадцяти осіб, відібраних місцевими громадськими об'єднаннями, але, на жаль, не всі погодилися на зустріч. Кілька чоловік відмовлялися згадувати минуле, бо не хотіли ще раз переживати, навіть у спогадах, жахливі події, хтось не хотів розповідати про свою участь у волонтерській діяльності через скромність, щиро вважаючи, що не зробив нічого особливого, а дехто перебував на передовій, в місцях, де продовжувалися конфлікти. 3 тими, що погодилися поділитися спогадами, домовлялися про зустріч у будь-який зручний для них час. Під час телефонної бесіди повідомлялася причина зустрічі, тема майбутньої розмови, висловлювалося прохання підібрати кілька фотографій, які б ілюстрували майбутню розповідь. Завдання попередньої телефонної розмови - націлити на співпрацю, дати час і можливість вибрати 3 великої кількості пережитих подій якусь одну чи кілька, обміркувати свою розповідь, підготуватися до розмови про важкий період життя. Переглядаючи вдома фотографії і вибираючи потрібні, респондент концентрувався на певних подіях, пригадував їх, що допомагало при особистій зустрічі. Як правило, опитувані вже знали, що саме вони хочуть розповісти і для чого.

До процесу інтерв'ювання були залучені студенти спеціальності «Журналістика». Про значення збору усних свідчень очевидців для дослідницької і виховної роботи студентів вищих навчальних закладів зазначали В. Кахновіч та Н. Кахновіч [11]. Під час підготовки до зустрічей акцентувалася увага на тому, що респонденти мають трагічний досвід, який слід враховувати. Детально обговорювалися прийоми і способи ведення бесіди, їі закінчення. Студентам пояснювалось, що ретельне продумування стимулюючих запитань (на випадок, коли респондент не знає з чого почати чи раптово замовкає і не може згадати про що ще розповісти), зацікавленість, спів- 
переживання та тактовність необхідні при розмові 3 людьми, що пережили трагічні події і мають болючі спогади.

Спочатку під час інтерв'ювання використовувалися технічні засоби, але майже одразу довелося від них відмовитися на користь стенографуванню, адже запис на диктофон для респондентів виявився некомфортним. До того ж, багато часу марнувалося на трансформування усного мовлення в письмовий текст. Інтерв'ю проводилося без заздалегідь підготовлених запитань, воно мало, скоріше, вигляд бесіди, що тривала від однієї до двох годин. Авторський колектив книги свідомо відмовився від складання опитувальника - респондентам не ставилися конкретні запитання, їм пропонувалося розповісти те, що найбільше запам'яталося чи вразило.

Варто зауважити, що західні практики напряму усної історії наголошують на необхідності зміни ситуації збору інформації за допомогою анкет чи опитувальників на ситуацію взаємодії, коли основна увага зосереджена на процесі, на динаміці. К. Андерсен і Д. Джек наголошують на тому, що інтерактивний характер співбесіди дозволяє робити пояснення, уточнення, замість очікуваних відповідей отримати особисту конструкцію власного досвіду. Такий перехід фокусу від збору даних до інтерактивного процесу впливає на якість отриманої інформації [12].

Інтерв’ю для книги «Герої згадують...» проводилося 3 кожним респондентом особисто. Саме таку побудову інтерв'ю вважає доцільною американський науковець Ч. Моррисей, додаючи, що багато чого залежить від кваліфікації інтерв'юера: скільки попередніх досліджень він зробив; скільки загалом інтерв'ю він вже провів і скільки - на певну тематику; чи було підготовче інтерв'ю, в якому обговорювалася процедура. Усі ці нюанси, на думку Ч. Моррисея, впливають на перебіг співбесіди [13].

Головним під час інтерв'ю було встановлення довірливих партнерських стосунків, що досягалося доброзичливим ставленням, уважним слуханням, відповідною очікуваною реакцією на почуте, обережними тактовними запитаннями. Респондент розповідав стільки часу, скільки вважав за потрібне. Його не перебивали, не виправляли мовні огріхи, не робили зауважень, не зупиняли. Бесіду проводили дватри студенти і викладач.

На нашу думку, інтерв'ю такого типу не доречно проводити одному досліднику, оскільки він зосереджений на збереженні почутої інформації, технічних моментах тощо. У таких умовах респонденту важко бути щирим і відвертим. У нього виникає відчуття, що його використовують як свідка, який щось бачив і може повідомити подробиці. Тому, хто розповідає, важливо бачити, що його розповідь не тільки фіксують, а й чують. Обов'язково повинні бути слухачі, які співчувають і симпатизують оповідачеві.

Як зауважують автори методичних рекомендацій 3 організації та проведення інтерв'ю Д. Титаренко та О. Титаренко, дослідник має виявляти інтерес до людини не лише як до джерела інформації, а й як до особистості, яка має унікальний життєвий досвід, свій власний світ почуттів, переживань, образів.
Завдання дослідника в процесі інтерв'ю полягає в тому, щоб не лише уявити собі цей світ, а й поставити себе самого у позицію респондента, інакше кажучи, побачити світ його очима [14]. Усі розповіді записувалися зі збереженням стилю викладу та змісту сказаного, мовних особливостей кожного оповідача. Після закінчення бесіди респондентам пропонувалося уважно перечитати свою розповідь, можливо, щось доповнити чи змінити. На цьому етапі уточнювалися деталі, пригадувалися подробиці подій. Іноді окремі фрагменти переписувалися чи взагалі викидалися на вимогу респондента. Дехто виявляв бажання доповнити розповідь через деякий час. Тоді призначалася повторна зустріч. Усні історії у книзі «Герої згадують...»є водночас методом збору свідчень та результатом. Вони відрізняються від традиційного журналістського інтерв'ю вищим ступенем персоналізації, емоційності та експресивносTi.

Після збору масиву усних історій виникло питання про композицію книги. Структура книги мала бути спрямована на всебічне висвітлення внеску мешканців Кременчука у перемогу. Матеріал можна було компонувати по-різному - за персоналіями, за хронологією тощо. Авторським колективом було вирішено покласти в основу композиції хронологічний принцип - спогади упорядковано по роках (від 2014 до 2018 року). Це, на наш погляд, дозволяє краще висвітлити динаміку подій і настроїв людей. Для компонування за хронологічним принципом спогади кожного респондента розбивалися на окремі фрагменти (історії конкретного року). Потім формувалися підрозділи книги, пов'язані з роками.

Свідченням учасників передує стисла історична довідка за кожний рік, у якій характеризуються події конкретного періоду АТО. Розташовані поряд сухі рядки історичної довідки і спогади конкретних людей дозволяють унаочнити епізоди війни. Наприклад, про події під Іловайськом розповідають бійці, які виходили з оточення, санітари, які вивозили поранених і загиблих, та волонтери, які допомагали потім шукати зниклих безвісті. Такий принцип побудови книги допомагає вибудувати цілісну картину, заповнити лакуни, що залишилися у свідомості українців, які знають про ці трагічні події лише із ЗМІ. На жаль, через різні причини багато чого 3 icторії цієї війни залишилося «за кадром», і усні історії учасників АТО та волонтерів покликані заповнити «білі плями» реальним життєвим матеріалом.

Послідовність подання свідчень зумовлена не характером матеріалу - усні історії йдуть за алфавітним принципом (перші літери прізвищ респондентів). Це спричинено бажанням авторів максимально уникнути суб'єктивізму, адже, коли журналіст чи редактор розміщує новини, він розуміє, що перша 3 них, як правило, сприймається як головна.

Для того, щоб майбутні читачі мали уявлення про кожного 3 героїв книги, в окремий підрозділ було винесено перелік респондентів 3 невеличкою біографічною довідкою про кожного учасника. Спочатку був розроблений алгоритм, за яким пропонувалося зробити довідку однаковою для всіх 3 певними анкетними даними, але під час бесіди багато хто 
відмовлявся надавати інформацію, відповідати на деякі запитання анкети, хтось не хотів повідомляти факти біографії, називати конкретні дати. Після кількох спроб зробити цей матеріал однотипним, було вирішено відмовитись від стандартних типових форм. Довідка узгоджувалася з респондентом (кожний учасник особисто вирішував, яку інформацію він хоче надати про себе і як він буде позиціонуватися у переліку: чи називати позивний, чи згадувати про нагороди тощо). Такий підхід до написання довідки зняв напругу і викликав довіру.

Наступним етапом після систематизації і компонування матеріалу (спогадів, історичних довідок, біографічних відомостей) стало редагування тексту. Оповіді учасників різнилися обсягом, використанням лексики, побудовою речень, емоційністю та експресивністю. Зрозуміло, що будь-яке втручання (скажімо, літературне редагування чи приведення до однотипності за якимись параметрами - кількість рядків, абзаців, сторінок тощо), можливо, зробить текст більш зручним для зорового сприйняття, але буде втрачено індивідуальність і неповторність кожного окремого інтерв'ю. Загальновідомим $є$ той факт, що особистість кожної людини, риси характеру, світогляд віддзеркалюється в іiі мовленні. Так, на зв'язок мовних особливостей та словникового запасу з соціальним станом вказує Д. Тофінг [15].

Авторський колектив свідомо відмовився від будь-якої інтерпретації та обробки спогадів. Пряма мова учасників підлягала лише необхідному редагуванню (зайві слова, слова-паразити, повтори, пунктуаційні помилки). Укладачі зберігали діалектизми, суржик і навіть подекуди неформальну лексику задля максимальної автентичності спогадів. Робота над стилістикою спогадів стала корисною для майбутніх журналістів і редакторів у аспекті формування мовної компетентності.

Після редагування тексту розпочалася підготовка ілюстративної частини. Студенти з фотографій, наданих респондентами, обирали найбільш інформативні та виразні світлини, які б гармонійно доповнювали текст. Потім обговорювалося оформлення обкладинки; здійснювалися написання передмови та післямови, укладання змісту та службової частини. На завершальному етапі рукопис було передано до видавництва. Процес підготовки видання тривав приблизно півроку. Готові книжки вручалися ветеранам АТО і волонтерам під час урочистого святкування Дня захисника Вітчизни 14 жовтня 2018 року.

ВИСНОВКИ. Підготовка книги «Герої згадують...» мала для кафедри видавничої справи та редагування Кременчуцького національного університету імені Михайла Остроградського велике значення в аспекті формування професійних компетентностей майбутніх журналістів, редакторів і видавців. Студенти, які входили до авторського колективу, на практиці ознайомилися з науковим напрямом усних історій та методом наративних інтерв'ю, навчилися проводити інтерв'ю, аналізувати результати, проводити редакторське опрацювання тексту, його компонування, художньо-технічне оформлення - тобто отримали навички підготовки книжкового видання на всіх етапах редакційно-видавничого процесу.
Книга «Герої згадують...» має певне практичне значення: зібраний матеріал можна використати у викладанні професійно-орієнтованих дисциплін спеціальності «Журналістика». Видання може використовуватися як дидактичний матеріал на навчальних заняттях з фахових дисциплін, пов'язаних з журналістикою, редагуванням і видавничою справою.

Важливою $є$ виховна функція книги. Під час роботи над створенням збірки студенти не лише навчаються принципам інтерв'ювання, вони дізнаються $з$ перших вуст про історію свого міста і країни. У виданні порушено важливі питання участі мешканців Кременчука у війні на сході, простежено динаміку подій на настроїв учасників. Книга розширює знання студентів про сучасну історію України.

Досвід підготовки книги допоможе у подальшій навчальній і науково-дослідній діяльності. Зацікавленість читачів і схвальні відгуки громади слугують аргументами на користь правильності обраної концепції видання.

Результати дослідження можуть лягти в основу подальшого наукового аналізу - осмислюватися у педагогічній, історичній, соціологічній, психологічній і у соціально-комунікаційній парадигмах.

\section{ЛІТЕРАТУРА}

1. Kenny M. G. A Place for Memory: The Interface between Individual and Collective History. Comparative Studies in Society and History. 1999. Vol. 41, No. 3. P. 420-437.

2. Rosenthal G. Biographical method - biographical research. Qualitative Research Practice / Ed. by S. Clive, G. Gobo, J. F. Gubrium, D. Silverman. London, 2004. P. 48-64

3. Грінченко Г. (Авто)біографічне інтерв'ю в усноісторичних дослідженнях: до питання про теорію наративного аналізу. Схід-Захід: історикокультурологічний збірник. Вип. 11-12. Спец. вид.: Усна історія в соціально-гуманітарних студіях: теорія і практика досліджень. Харків: ТОВ «НТМТ», 2008. C. 59-76.

4. Кісь О. Усна історія: становлення, проблематика, методологічні засади. Украӥна модерна. Т. 11. 2006. С. 7-24.

5. Нагайко Т. Усна історія: міждисциплінарний діалог гуманітарних студій. У пошуках власного голосу: Усна історія як теорія, метод та джерело: зб. наук. ст. Харків: ПП «ТОРГСІНПЛЮС». 2010. С. $160-170$.

6. Дьяковська Г. Наратив як складова дискурсивної реальності. Схід. № 5 (151). 2017. С. 70-73. DOI: 10.21847/1728-9343.2017.5(151).117405

7. Ярощук О. Оцифровані спогади, або як творити усну історію. URL: http://ms.detector.media/web/online_media/otsifrovani_ spogadi_abo_yak_tvoriti_usnu_istoriyu/ (дата звернення: $12.10 .201 \overline{8}$ ).

8. Розенталь Г. Реконструкция рассказов о жизни: принципы отбора, которыми руководствуются рассказчики в биографических нарративных интервью. Хрестоматия по устной истории. СПб: изд-во ЕУСПб, 2003. С. 322-355. 
9. Лапан Т. Д. Репрезентація збройного конфлікту на сході України в жіночих біографічних інтерв’ю. Вісник Львівського університету. Серія сочіологічна. 2017. Вип. 11. С. 159-172. DOI:10.30970/vso.2017.11.14

10. Пастушенко Т. Метод усної історії та усноісторичні дослідження в Україні. Історія України. 2010. № 17-18. С. 10-15.

11. Кахновіч В. А. «Вельмі ж мне надаела вайна за 4 гады...»: до питання про виховну складову вивчення історії. Сторінки історії. 2017. № 44. URL: http://history-pages.kpi.ua/blog/2017/07/13 DOI: 10.20535/2307-5244.44.2017.105461 (дата звернення: 07.10.2018).
12. Anderson K., Jack D. C. Learning to listen: interview techniques and analyses. The oral history reaer. London, New York, 2003. P. 157-171.

13. Morrissey Ch. T. On oral history interviewing. The oral history reader. London, New York, 2003. P. 107-113.

14. Титаренко Д. Дослідницьке інтерв'ю: методичні рекомендації з організації та проведення дослідження. К.: ТОВ «Праймдрук», 2012. 40 с.

15. Torfing J. Discourse Theory: Archivments, Arguments, and Chellengers. Discourse Theory in European Politics. Identity, Policy and Governance. Palgrave $\quad$ Macmillan, $2005 . \quad 349 \quad$ p. DOI: 10.1057/9780230523364_1.

\section{CREATING A BOOK OF MEMOIRS OF ATO PARTICIPANTS: FROM THE IDEA TO THE COMPLETE EDITION}

\section{K. Sizova, N. Alekseenko}

Kremenchuk Mykhailo Ostrohradskyi National University

vul. Pershotravneva, 20, 39600, Kremenchuk, Ukraine. E-mail: sizovakl@ ramblerl.ru

Purpose. The paper deals with the process of creating a book of memoirs of ATO participants and volunteers from Kremenchuk, which was attended by students and teachers of the Department of Philology and Publishing at the Kremenchuk Mykhailo Ostrogradskyi National University. Methodology. The research was conducted using systematic and interdisciplinary approaches, with the help of general scientific methods: analysis, synthesis, comparison, induction and deduction, as well as descriptive method. Findings. Different stages of edition preparation are considered - from concept development to replication. Particular attention is paid to the method of narrative interviews. It emphasizes the interdisciplinary nature of the direction of oral history, its connection with the sciences on social communications. Teachers and students in practice became acquainted with the scientific direction of oral history and the method of narrative interviews, learned how to interview, analyze the results, and learned the skills of preparing the publication at all stages of the editorial and publishing process. The experience of preparing a book will help in the next academic and research activity. Originality. The scientific novelty consists in the fact that the article consistently reviewed the process of preparing the book of memoirs by the method of narrative interviews from the idea to the finished publication. Practical value. The book «Heroes remember ...» has some practical value: the collected material can be used in the teaching of professionally oriented subjects of the specialty «Journalism». The educational function of the book is important - students not only learn the principles of interviewing, but also, the history of their city and country. Conclusions. The creating of the book was of great significance for the Kremenchuk Mykhailo Ostrogradskyi National University. Teachers and students who belonged to the author's team, in practice, became acquainted with the scientific direction of oral history and the method of narrative interviews, learned to interview, analyze the obtained results, and received the skills of preparing the publication at all stages of the editorial and publishing process. This experience will help in the next academic and research activity. The interest of the readers and the approving comments of the community serve is an argument in favor of the correctness of the chosen concept of the book.

Key words: memory book, edition concept; ATO participants, method of narrative interviews, oral history, professional journalistic competencies

\section{REFERENCES}

1. Kenny, M. G. (1999), "A Place for Memory : The Interface between Individual and Collective History", Comparative Studies in Society and History, vol. 41, no 3, pp. 420-437.

2. Rosenthal, G. (2004), "Biographical method biographical research", Qualitative Research Practice, London, pp. 48-64.

3. Hrynchenko, H. (2008), “(Avto)biohrafichne interv'yu $\mathrm{V}$ usnoistorychnykh doslidzhennyakh: do pytannya pro teoriyu naratyvnoho analizu" [Auto)biographic interview in oral historic researches: regarding the theory of narrative analysis], Skhid-Zakhid: istoryko-kul'turolohichnyi zbirnyk [East-West: Historical and culturological journal], vol. 11-12, JSC "NTMT", Kharkiv, pp. 59-76.

4. Kis, O. (2006), "Usna istoriya: stanovlennya, problematyka, metodolohichni zasady" [Oral history: problem statement, development, methodological basis], Ukrayina moderna [Modern Ukraine], vol. 11, pp. 7-24.
5. Nahaiko, T. (2010), "Usna istoriya: mizhdystsyplinarnyy dialoh humanitarnykh studiy" [Oral history: interdisciplinary dialog of humanities studies], U poshukakh vlasnoho holosu: Usna istoriya yak teoriya, metod ta dzherelo [In search of proper voice: Oral history as theory, method and source], PE Torhsinplus, Kharkiv, pp. 160-170.

6. Diakovska, G. (2017), "Naratyv yak skladova dyskursyvnoyi real'nosti" [Narrative as a component of diskoursive reality], Skhid [East], no 5 (151), pp. 70-73. DOI: $10.21847 / 1728-9343.2017 .5(151) .117405$

7. Yaroshchuk, O. (2016), "Otsyfrovani spohady, abo yak tvoryty usnu istoriyu" [Digital memories, or How to create oral history], Detector Media, URL: http://ms.detector.media/web/online_media/otsifrovani_ spogadi_abo_yak_tvoriti_usnu_istoriyu/ (accessed 12, October 2018). 
8. Rosental, G. (2003), "Rekonstruktsiya rasskazov o zhizni: printsipy otbora, kotorymi rukovodstvuutsya rasskazchiki v biograficheskikh narrativnykh interv'u" [Reconstruction of narratives about life: principles of selection which narrators of biographical narratives interviews are guided with], Khrestomatiya po ustnoy istorii [Anthology on oral history], EUSPb publishing house, $\mathrm{SPb}$, pp. 322-355.

9. Lapan, T. D. (2017), "Reprezentatsiya zbroynoho konfliktu na skhodi Ukrayiny $\mathrm{v}$ zhinochykh biohrafichnykh interv'u" [Representation of armed conflict in the East of Ukraine in the women's biographical interview], Visnyk L'vivskoho universytetu [Visnyk of the Lviv University]. Series Sociology, Issue 11, pp. 159-172. DOI:10.30970/vso.2017.11.14

10. Pastushenko, T. (2010), "Metod usnoi istorii ta usnoistorychni doslidzhennya v Ukraini" [The method of oral history and oral historical researches study in Ukraine], Istoria Ukrainy [History of Ukraine], no $17-$ 18, pp. 10-15.

11. Kahnovìch, V. A., Kahnovìch, N. A. (2017), "Vel'mi zh mne nadaela vayna za 4 hady...: do pytannya pro vykhovnu skladovu vyvchennya istorii"
[Velmi j mne nadoela waiana za 4 gady...: to the problem of educational component of the history studying], Storinky istorii [The pages of history], no 44, URL: http://history-pages.kpi.ua/blog/2017/07/13 DOI: 10.20535/2307-5244.44.2017.105461 (accessed 07, October 2018).

12. Anderson, K., Jack, D. C. (2003), "Learning to listen: interview techniques and analyses", The oral history reader, London, New York, pp. 157-171.

13. Morrissey, Ch. T. (2003), "On oral history interviewing", The oral history reader, London. New York, pp. 107-113.

14. Tytarenko, D. (2012), Doslidnyts'ke interv'yu: metodychni rekomendatsiyi $z$ orhanizatsiyi ta provedennya doslidzhennya [Research interview: methodological recommendations on organizing and carrying out of research], Prajmdruk, Kyiv, Ukraine.

15. Torfing, J. (2005), "Discourse Theory: Archivments, Arguments, and Chellengers", Discourse Theory in European Politics. Identity, Policy and Governance, Palgrave Macmillan. DOI: 10.1057/9780230523364_1. 